\title{
The Development of Learning Material Model in Writing Scientific Papers by Using Guided Inquiry Method at Universitas PGRI Sumatera Barat
}

\author{
Lira Hayu Afdetis Mana \\ Universitas PGRI Sumatera Barat \\ email: lirahayuam@gmail.com
}

\begin{abstract}
This research is motivated by the difficulties of students in determining the topic of scientific writing, difficulties in conveying ideas and limitations of references. This study aims to develop a learning model for writing scientific papers using the guided inquiry method. This type of research is development research. This study uses a 4-D development research design. The results of this study are as follows: (1) the material for writing scientific papers is difficult because students do not understand the concept of Scientific Writing. (2) in developing scientific work students do not yet know the systematics of scientific writing and students often make ineffective sentences (3) students really need freedom in determining writing topics and ideas (4) most students need the concept of learning to write scientific papers, (5) most students need lecturer guidance in their writing, (6) most students need systematic scientific work concepts, (7) most students need lots of references to write scientific papers. Based on the analysis of student needs, it is necessary to develop a Guided Inquiry-Based Scientific Writing Textbook that provides opportunities for students to find their own concept of learning to write scientific papers. Through Guided Inquiry, students are trained to think critically with teacher guidance.
\end{abstract}

Keywords: Writing Scientific Papers, Guided Inquiry Method

\section{Introduction}

The culture of writing has now been replaced by a copy-paste culture which causes students to be lazy to write. There is no more awareness of learning to write and make your own analysis. (Rusnaf, 2014). This is what causes students' writing mentality to get lower. Most of the students do not understand the importance of writing for their future life. As a student, one of the requirements to achieve a bachelor's degree is to write a scientific paper in the form of a thesis (Saman \& Bakhtiar, 2018). Writing scientific papers stems from a problem. To be able to solve problems, researchers must understand the origin of the problem by looking for many theories. The accumulated theory is summed up and forms a new understanding. Even these new understandings must be combined with field data so that they are not only narrow-minded. Field data can be retrieved by observation, distributing questionnaires, interviews and others. The data that has been obtained are then combined with theory and produce conclusions (Kurniadi, 2017). The systematic of writing scientific articles such as the opening, introduction, discussion, research methodology, research results, closing and supporting sections (Rosmiati, 2017).

Learning to write scientific papers is a compulsory subject that must be followed by university PGRI Sumatera Barat students. Based on the standards of the Indonesian National Qualifications Framework, the output of the scientific paper writing course is to produce scientific papers in the form of scientific articles. Scientific articles are scientific articles that can be in the form of review articles or research 
articles from research reports that are rewritten by the authors to be published in reputable scientific journals. (Nurul Rafiqo, Agus Perdana Windarto, Anjar Wanto, 2018 )

Writing scientific articles is also important for teachers, especially for teacher brokers and for teachers. To become a professional teacher, there is a need to have scientific work when applying for promotion. This is in accordance with the mandate of the Regulation of the Minister of State for State Apparatus Empowerment and Bureaucratic Reform Number 16 of 2009 concerning Teacher Functional Positions and Credit Score. But the fact is that there are still many teachers who are still weak in their ability to write scientific papers. This is due to the limited access to information and mastery of the scientific method. Therefore it is important for teachers to know and learn about writing scientific papers. (Imam Gunawan, Triwiyanto, Desi Eri Kusumaningrum, 2018).

How to write excellent articles for leading academic journals. An article published in a scientific journal suggests that effective writing requires conditions: (1) focused on the topic and does not contain unrelated elements; (2) have an organizational pattern that allows readers to follow the flow of ideas because they contain a beginning, middle and end that use transitions or transitions; (3) using supporting ideas; (4) following the agreed rules (Samra, 2001: 2). Writing and Publishing Scientific Papers (El Serag, 2012). Journal publishing challenges: The case of the STM scientific journal in Croatia. The fast publication of articles is essential for faster access to accumulated scientific knowledge (Vrana, 2012). This shows that writing scientific papers is needed by all countries, especially those who are in the academic realm.

The results showed that the average ability to write scientific papers from the Indonesian language study program and literature education in Padang was in the more than adequate category. (Alfianika, Sunendar, Sastromiharjo, \& Damaianti, 2019). The first step that can be taken to solve this problem is to conduct a needs analysis. Needs analysis was first introduced in India in 1920 (West, 1994). Needs analysis is an activity of gathering information as a basis for developing something that can meet the needs of a group of students (Songhori, 2008). Needs analysis is a process carried out to obtain information. Needs analysis can be used for various purposes (Pushpanathan, 2013).

The problem that often occurs in learning to write scientific papers is that lecturers are often the center of learning and students are only the object of listeners. What is given dominantly is in the form of theories and concepts of scientific writing. Other problems obtained from interviews with students are difficulties in determining the topic of scientific writing, limited references related to scientific writing, difficulty conveying ideas and composing appropriate words.

Based on the needs analysis conducted, it was found that students wanted guided learning, starting from determining topics, understanding the components of scientific writing, and developing scientific writing. Students prefer learning that is guided by lecturers to be given questions and problems in learning to write scientific papers. Therefore, researchers developed guided inquiry-based teaching materials. Guided inquiry is a method that directs students to find concepts based on orientation, formulate problems, create hypotheses, collect information and process information, test hypotheses and conclude. In guided inquiry, the teacher / lecturer guides students to carry out activities by giving initial questions and leading to a discussion. Then the teacher raises the problem, gives directions about solving, and guides students in recording data.

\section{Textbook of Writing Scientific Papers}

Textbooks are a type of book that can be used by learners and teachers / lecturers in the teaching and learning process; usually textbooks contain explanations of learning objectives, learning materials, instructional media, teacher / lecturer and student / student guides, basic exercises and enrichment, and structured assignment suggestions / answers. 


\section{Guided Inquiry Approach}

Inquiry comes from the English language which can be interpreted as the process of asking and finding out answers to the scientific question being asked. Inquiry learning strategies are a series of learning activities that emphasize critical and analytical thinking processes to seek and find answers to a problem in question. The learning process by inquiry follows these steps:

1. Orientation

Orientation is a step taken by the teacher to condition students to be ready to carry out the learning process.

2. Formulation of the problem

Formulating a problem is a step to bring students on a problem.

3. Hypothesis

The hypothesis is a temporary answer to a problem that is being studied.

4. Data Collection

This stage is the activity of capturing the information needed to test the proposed hypothesis. In guided inquiry, collecting information is carried out jointly between the teacher and students.

5. Hypothesis Testing

Hypothesis testing is the process of determining which answers are considered acceptable in accordance with the data and information obtained based on data collection.

6. Formulation of the conclusion.

Formulating the conclusion is the process of describing the findings obtained based on the results of hypothesis testing.

Guided inquiry learning is a model of inquiry learning in which the teacher provides sufficient guidance or guidance to students. Piaget argues that the inquiry model is a model that prepares students in situations to carry out their own experiments broadly in order to see what is happening, want to find their own answers and relate their findings to other findings, then compare what is found with what other students find.

\section{Methods}

This type of research is development research. Development Research is a sequential set of procedures to carry out design and development which is manifested in the form of a process of learning to write scientific papers. It can also be defined as a research method that is used to produce certain products and test the effectiveness of these products (Sugiyono, 2012: 407). The research design used in this research is the 4-D model development research design (Four D Models). According to Thiagarajani, this includes 4 stages, namely the stage of defining (define), design (design), development (develop) and dissemination (disseminate). This research was conducted in the 6th semester of the students of the Department of Indonesian Language and Literature Education University of PGRI West Sumatra, class of 2018, totaling 105 samples.

\section{Result and Discussion}

The stages of development are carried out using a 4-D development model. However, in this article the author only does 2 stages, namely Defining and Designing.

\section{A. Defining}

What is done at this stage is to see the initial conditions of learning to write scientific papers and then analyze them. The results obtained from this stage are as follows:

\section{1) Analysis of RPKPS for Teaching Subjects for Scientific Writing}

Syllabus analysis is carried out to see the material that has been taught is in accordance to the Subject Learning Outcomes. The subject learning outcomes of Scientific Writing is that students are able 
to understand basic theories in writing scientific papers, be able to understand the concepts and techniques of writing scientific papers (initial part, middle part, final part), able to analyze the writing of scientific papers in the implementation of learning Indonesian language and literature. apply the concepts and techniques of writing scientific papers to produce scientific writing. Then, they are able to apply the concept of writing Scientifics papers to develop oral and written communication skills for various purposes.

From these results, it was found that the material in the syllabus was in accordance with the competencies that must be achieved by students. The order of the material has also been correct because the material consists of ten chapters and consists of 16 Learning Activities.

\section{2) Analysis of Peers Interview Results}

Peer interview aims to find out the problems faced during the learning process on the material of writing scientific papers. Interviews were conducted with 2 colleagues on April 21, 2021. Based on the results of the interviews, it was found that the material for writing scientific papers was difficult because students had not understood the concept of writing scientific papers well, especially in making direct or indirect quotations. Then, another problem is in developing scientific writing contents. In this case, the students do not know the systematic of Scientific Writing so that they are unable to write effective sentences inside their scientific papers.

\section{3) Analysis of the Student Needs Questionnaire}

The student needs questionnaire aims to find out the student's needs for the concept of learning, the need for lecturer guidance, the need for determining topics and ideas for scientific papers, media, references in relation to lectures in teaching Scientific Writing. The questionnaire is distributed to students who take scientific writing lectures. From the questionnaire that was filled in by the students, the following conclusions were obtained:

a. The need for freedom in determining topics and ideas for scientific writing.

\section{Saya membutuhkan kebebasan dalam menentukan topik dan ide karya tulis ilmiah}

106 jawaban
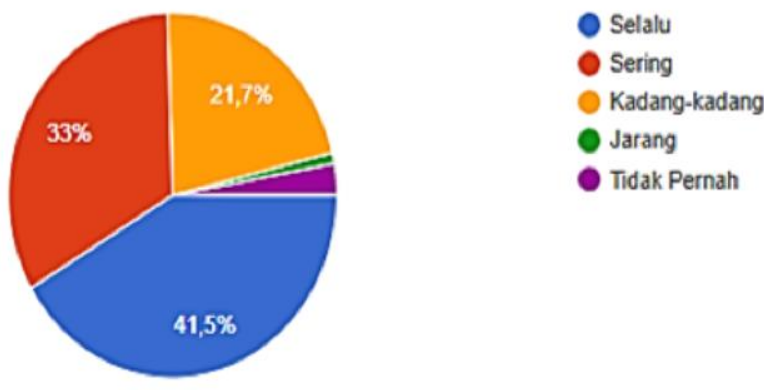

From the diagram above, it can be seen that students need freedom in determining topics and ideas for scientific papers by $41.5 \%$ (always), $33 \%$ (often), $21.7 \%$ (sometimes), and only a few are rare and never. Hence, it can be concluded that students mostly need freedom in determining the topics and ideas of scientific writing. 
b. The need for the concept of learning to write scientific papers.

7. Saya membutuhkan konsep pembelajaran menulis karya ilmiah

105 jawaban

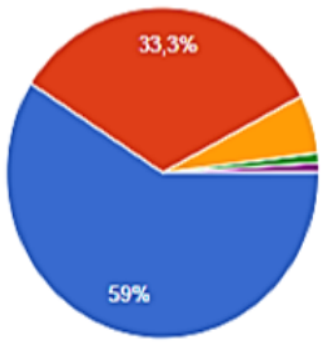

From the diagram above, it can be seen that students need the concept of learning to write scientific papers by 59\% (always), 33\% (often), and only a few say sometimes, rarely and never. So, it can be concluded that students mostly need the concept of learning to write scientific papers.

c. The need for guidance in writing scientific papers

9. Saya membutuhkan bimbingan dosen dalam menulis artikel ilmiah.

108 jawaban


Based on the diagram above, it can be seen that students need lecturer guidance in writing scientific articles by $72 \%$ (always), $17.6 \%$ (often), $10.2 \%$ sometimes. So, it can be concluded that most students need guidance from lecturers in writing scientific articles. 
d. The need for a systematic concept of writing scientific papers

11. Saya membutuhkan konsep sistematika penulisan karya tulis ilmiah

110 jawaban
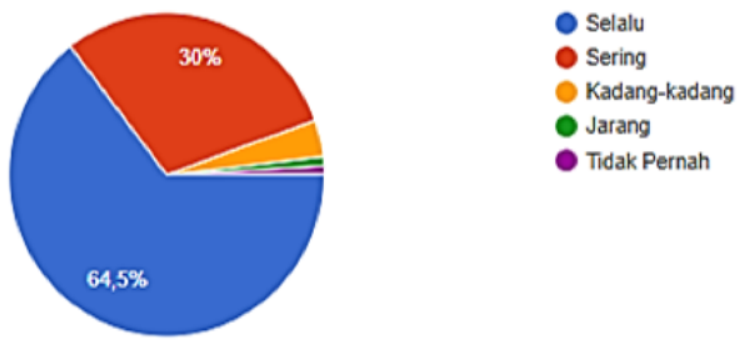

Based on the diagram above, it can be seen that students need a systematic concept of writing scientific papers by $64.5 \%$ (always), $30 \%$ often, a little sometimes. So, it can be concluded that most students need a systematic concept of writing scientific papers.

e. The need for the availability of references to write scientific papers

20. Saya membutuhkan referensi yang banyak untuk menulis karya ilmiah.

110 jawaban
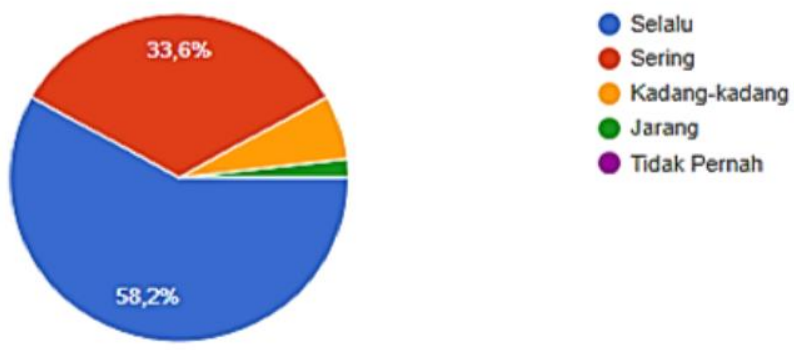

Based on the diagram above, it can be seen that students need a lot of references to write scientific papers of $58.7 \%$ (always), 33.6\% (often) and few say sometimes and rarely. So, it can be concluded that most students need a lot of references to write scientific papers.

\section{4) Textbook Analysis}

Textbooks are designed and developed aiming to help students understand the material in the teaching of Scientific Writing. However, so far students only use textbooks related to Scientific Writing. The problem is that the material contained in the textbook does not match the material contained in the syllabus. So that students are forced to look for other teaching materials, but they don't find it easily.

In addition, the textbooks they use for learning do not contain evaluations and exercises related to writing scientific papers. In it dominantly contains theories about Scientific Writing only. There is an evaluation 
in the book. but still evaluating the understanding of theory, not training and guiding how to write good and correct scientific papers.

This guided inquiry-based scientific writing textbook is made in stages to train students to be skilled in writing scientific papers, this textbook for writing guided inquiry-based scientific work contains Learning Outcomes of Competencies related to KKNI, Learning Materials, Summary, List of References and Assessment designs. Textbook and lectures of writing Scientific Papers use the Guided Inquiry Method which makes it easy for students to learn to write scientific papers by finding concepts through problem identification, but still guided by lecturers. This textbook encourages students to construct their own knowledge, participate actively, have independent learning abilities and can develop their own knowledge actively. The lecturer acts as a facilitator.

\section{B. Designing}

At the design stage, namely preparing the initial design of textbook development Writing Guided Inquiry-based Scientific Work includes: RPKS development, Lecture Program Unit (SAP), Guided Inquiry-based textbooks which begin with designing a draft design. Then proceed with the creation of SAP and textbooks based on the draft design.

\section{(1) Constructing RPKPS}

The RPKPS is made based on the draft that has been prepared. In the RPKPS there are course identities, course descriptions, learning outcomes, competencies (general and specific), number of hours (time allocation), lecture design outline, assignments and exercises, assessments, lecture rules and references. In more detail, the Lecture Design Outline contains the following items: week / meeting, expected abilities, subject matter, learning methods (in this case the Guided Inquiry Method) which are distributed and adjusted to the material and learning objectives. Then the student exercises.

\section{(2) SAP Creation}

SAP is made based on a draft that has been compiled. Evaluation is very important at this stage of making SAP. The evaluation used in making this SAP is self-evaluation. The SAP design was selfevaluated by the researcher using self-evaluation guidelines then analyzed and revised based on the results of the self-evaluation. Data from the SAP manufacturing stage are presented based on aspects of ease of use, and aspects of time compatibility.

\section{(3) Development of Textbook for Writing Scientific Papers Based on Guided Inquiry}

The of textbooks is made based on the draft of textbook design that has been compiled. In the textbook, each chapter contains the steps of the Guided Inquiry Method, namely:

1. Orientation

2. Formulation of the problem

3. Hypothesis

4. Data Collection

5. Hypothesis Testing

6. Formulation of the conclusions

\section{Conclusion}

Based on the research, it can be concluded that: (1) the material in the syllabus is in accordance with the competencies that must be achieved by students, both in content and in order; (2) the material of writing scientific papers is classified as difficult because students do not understand the concept of writing scientific papers well, especially making direct or indirect quotations; (3) in developing scientific 
papers, students do not know the systematic of scientific papers and students often make ineffective sentences; (4) most students need:

a) Freedom in determining topics and ideas for scientific papers.

b) The concept of learning to write scientific papers.

c) Lecturer guidance in writing scientific articles

d) The systematic concept of writing scientific papers.

e) Many references to writing scientific papers

Based on the analysis of students needs, the Development of Guided Inquiry-Based Scientific Writing Textbooks needs to be done, because these textbooks provide opportunities for students to discover for themselves the concept of learning to write scientific papers through orientation, formulate problems, submit hypotheses, collect data, test hypotheses and formulate conclusions. Through Guided Inquiry, students become trained to think critically to seek and find answers to a question in question, but still under the guidance of the teacher.

\section{References}

Alfianika, N., Nofasari, E., \& Marni, S. (2018). Penerapan metode dalam pembelajaran menulis karya ilmiah berbasis hots [application of methods in learning to write scientific papers based on hots]. Bandung: Prodi Pendidikan Bahasa Indonesia SPs UPI.

Derish, PA, Maa, J., Ascher, NL, \& Harris, HW (2007). Enhancing the mission of academic surgery by promoting scientific writing skills. Journal of Surgical Research, 140(2), 177-183.

Ecarnot, F., Seronde, M.-F., Chopard, R., Schiele, F., \& Meneveau, N. (2015). Writing a scientific article: A step-by-step guide for beginners. European Geriatric Medicine, 6(6), 573-579. https://doi.org/10.1016/j.eurger.2015.08.005

Jauhari, H. (2013). Terampil mengarang: Dari persiapan hingga presentasi dari opini hingga sastra (Herman Aksan, Vol. 2). Bandung : Nuansa Cendekia.

LaPlaca, P., Lindgreen, A., \& Vanhamme, J. (2018). How to write really good articles for premier academic journals. Industrial Marketing Management, 68, 202-209.

Press. Pushpanathan, LT (2013). A need for needs analysis. 7. Songhori, MH (2008). Introduction to Needs Analysis. (4), 25.

Syaefullah, A. (2015). Prinsip dasar penyusunan dan penulisan karya tulis ilmiah [The basic principles of the preparation and writing of scientific papers]: The fundamental of scientific writing (Vol. 1). Jakarta: PT Grasindo.

West, R. (1994). Needs analysis in language teaching. Language Teaching, 27(1), 1-19. 